\title{
Human resource management practices in a Russian commercial bank in the context of an innovative economy
}

\author{
Sergey Shaytura ${ }^{1, *}$, Azat Madyarov ${ }^{2}$, Konstantin Ordov $^{3}$, and Sergey Filimonov ${ }^{4}$ \\ ${ }^{1}$ Russian University of Transport (MIIT), Moscow 127994, Moscow, Russian Federation \\ ${ }^{2}$ Humanitary, economic and informatic technology institute, Burgas 8000,Burgas, Bulgaria \\ ${ }^{3}$ Financial University under the Government of the Russian Federation, Moscow 117997, Moscow, \\ Russian Federation \\ ${ }^{4}$ Russian University of Tourism and Service, Moscow 141221 Moscow, Russian Federation
}

\begin{abstract}
This article examines the specifics of human resource management in the context of the promotion of an innovative economy. The study of the human resource management practices in Sberbank of Russia is highly relevant due to the challenges and external threats Russia currently faces and must respond to. The findings made following the analysis of the bank's reports, surveys, and other open-source information indicate Sberbank's high readiness to respond to the challenges typical of the new strategic context. At the same time, certain elements are identified without which such organizations operating in the conditions of the digital economy will not be able to outdo their competitors in the future. Sberbank has successfully implemented the Development Strategy through the consistent introduction of human resource management practices that correspond to the current trends involving the development of the information society. It is suggested that the range of tools used to establish an innovation-oriented environment be expanded with organizational democracy and agile leadership.
\end{abstract}

\section{Introduction}

At the end of 2020, the second phase of the government program for innovative development of the Russian economy in 2008-2020 was completed. To summarize the development of the innovative economy in Russia, the progress at different levels must be evaluated. Alongside government regulation, it is the behavior of the program stakeholders, i.e., market players, that mattered for the successful implementation of the Russian development strategy. For this reason, it is important to study the human resource management practices in Sberbank, which has managed to successfully implement Development Strategy 2020.

\footnotetext{
*Corresponding author: swshaytura@gmail.com
} 


\section{Materials and Methods}

Approved in 2008, the Concept for the Long-Term Socio-Economic Development of the Russian Federation for the Period until 2020 ("the Concept") included two phases and focused on several areas. According to the Concept, to achieve the level of economic and social development that would correspond to Russia's status as the $21^{\text {st }}$-century superpower and global leader, several tasks must be fulfilled[1]:

1) Build a competitive knowledge economy,

2) Promote trust and responsibility, leadership, and innovation,

3) Improve the welfare of Russian people up to the level of developed countries.

The Concept establishes the main drivers for the transition to innovation-oriented development:

1) Human intelligence and creativity as the main force behind economic growth and national competitive position,

2) New ideas and socio-technical innovations,

3) Advanced human resource development:

- Creating favorable conditions for human resource development,

- Business's proactive approach to human capital development,

- Partnership-based employer-employee relations,

- Promoting high work ethics,

- Improving the competitive advantages of human capital.

Recognizing the importance of human resource development in the new economic environment, the authors of the Concept rightly pointed out that entities dealing with intense global competition have the greatest need for managerial and social innovations [25]. According to the Concept, the innovative economy model requires a breakthrough improvement of human capital performance.

Even though from the strategic point of view, it is sectors and markets, not countries, that become globalized, entities' global strategies influence cross-national relations: global industries emerge, competitive advantage is achieved through global action.

The globalization of markets and industries occurs in the context of the emergence of an information society when post-industrialism becomes a favorable environment for the information revolution [6-8]:

1)a service society, for which knowledge is the main resource, generates demand for highly qualified employees and managers,

2)the main attribute of an innovative economy is its reliance on business and professional services, knowledge industry,

3)globalization leads to universalization, homogenization, and unification of institutions and processes.

The standardization of product and service specifications, the unification of the customer value chain, the universalization of business processes - all this increases the availability of products and services while reducing the costs and improving labor productivity. The principles of the modern-day innovative digital economy shape the competition between companies in the $21^{\text {st }}$ century $[9,10,11]$ :

1) openness - attractiveness for the external labor market, ability to hire, motivate, develop, and retain the best professionals from the outside, without relying solely on current employees,

2) peering - using self-organization to establish horizontal ties, rejection of the topdown approach, which is detrimental to the competitive ability in the context of a new economy,

3) sharing - intellectual openness as an approach to cooperation and creating flexible business ecosystems, 
4) globalness - creating and using a single platform to improve cooperation between different business sections and elements, thus ensuring access to new markets, ideas, and qualified employees.

Since 1993, Bain \& Company consulting firm has been regularly conducting surveys of entrepreneurs around the world and publishing annual reports providing: 1) a review of trends in the use of management tools; 2) a summary of top 25 management tools. Deloitte and its Russian subsidiary Deloitte Consulting also publish annual global and local research reports on HR trends.

\section{Results}

The challenges recognized at the national level become threats which the leading entities as participants in the socio-economic relations must respond to. Sberbank as a publicly held company and the "flagship of digital transformation" has been chosen as an example through which the human resource management practices will be studied [12 - 14]:

1)the bank does not simply introduce new technology into its business processes but also invests money in their development and promotion at the national level,

2)having mastered the methods of successful transformation over the years of implementing the strategy, the bank's management team has all the skills modern managers are supposed to have both in relation to conventional management practices and in relation to understanding innovative technologies [15 - 17].

In the context of an innovative economy, the concept of the Russian government (as a nationwide regulator) and the business model of Sberbank (as a strategic bank) include, as a response to external challenges, the creation and implementation of a comprehensive set of measures to ensure the promotion of innovative processes, built around human resources:

1)the "development formula" proposed by the authors of the Concept can be described as follows: "organizational democracy — highly qualified employees — high technologies",

2) according to Sberbank's 2019 reports, the bank's human resources are its key stakeholders.

According to Herman Gref, President of Sberbank, "the main tasks of Strategy 20182020 have been fulfilled so that the organization can now move to the next phase" [18 20]. The largest player in the Russian financial service market has managed to build advanced development mechanisms to respond to the challenges of an innovative economy. The HR management tools proposed in Strategy 2018-2020 have proven their feasibility in the current conditions. Therefore, the study of the bank's use of such human resource management tools will make it possible to spread Sberbank's "best practices" to other sectors, with due account of the specifics of implementing the lending institution's development strategy.

In the context of digital globalization leading to increased competition across industrial and national borders, innovation-related aspects of management are of particular interest. Global leaders in management consulting regularly research the use of strategic, general, and HR management tools. In their reports, Bain and Deloitte pay special attention to the latest management techniques and their use.

Sberbank's efficiently operating organizational system provides mechanisms to respond to the challenges of the digital economy (see Table 1 for the insights). The bank's business model includes reliance on the concept of strategic human resource ("HR") management. According to this concept, employees are the company's primary asset, with all managers charged with responsibility for HR management, and with the HR management policy integrated into the development strategy to ensure the achievement of the goals and objectives. 
Table 1. Challenges and responses at different levels of the Russian economy

\begin{tabular}{|c|l|c|c|}
\hline \multirow{2}{*}{ No. } & \multicolumn{1}{|c|}{$\begin{array}{c}\text { Challenge } \\
\text { (Concept) }\end{array}$} & $\begin{array}{c}\text { Tools for responding to external threats / } \\
\text { Responses to the challenges of the digital economy }\end{array}$ \\
\cline { 3 - 5 } & \multicolumn{1}{|c|}{ Concept } & $\begin{array}{c}\text { Sberbank's } \\
\text { business model }\end{array}$ \\
\hline 1. & $\begin{array}{l}\text { Increasing global } \\
\text { competition }\end{array}$ & $\begin{array}{c}\text { support systems for innovation } \\
\text { and human development }\end{array}$ & $\begin{array}{c}\text { competition with } \\
\text { global tech } \\
\text { companies }\end{array}$ \\
\hline 2. & $\begin{array}{l}\text { Predicted wave of } \\
\text { technological } \\
\text { innovations }\end{array}$ & $\begin{array}{l}\text { increasing strategic presence in } \\
\text { the sectors of high-tech products } \\
\text { and knowledge-based services }\end{array}$ & $\begin{array}{l}\text { software: IT } \\
\text { platform, innovative } \\
\text { infrastructure }\end{array}$ \\
\hline 3. & $\begin{array}{l}\text { Increasing role of } \\
\text { human capital }\end{array}$ & $\begin{array}{l}\text { development formula: } \\
\text { "democracy - man - } \\
\text { technology" }\end{array}$ & $\begin{array}{c}\text { employees as key } \\
\text { stakeholders }\end{array}$ \\
\hline 4. & $\begin{array}{l}\text { Exhausted potential of } \\
\text { the industrial model } \\
\text { of economic } \\
\text { development }\end{array}$ & $\begin{array}{l}\text { development of the national } \\
\text { innovation system; coordination } \\
\text { of education, science, and } \\
\text { business }\end{array}$ & $\begin{array}{c}\text { value drivers: } \\
\text { corporate culture, } \\
\text { customer relations, } \\
\text { and social } \\
\text { responsibility }\end{array}$ \\
\hline
\end{tabular}

Sberbank's management team achieves business development at different levels by introducing HR practices (see Table 2 for the insights) that correspond to the global trends:

1)at the individual level:

- developing a digital mindset (as a digital transformation challenge),

- promoting digital literacy among bank employees,

2)at the group level:

- encouraging work in "horizontal teams" and a collaborative spirit,

- creating a platform for small organizations, teams,

- practicing the improved teamwork approach that requires the "co-creation" skill,

- actively implementing Agile Management [12] to reflect the increasing role of technology in management (as a tool popular among software developers),

3)at the organizational level:

- managing the systemic digital transformation,

- creating a "total business ecosystem" based on the bank's software platform.

The review of the current HR concepts, management tools, and solutions applied by Sberbank demonstrates the importance of human resources for an innovative company. Sberbank's HR practices' compliance with the international management standards suggests that they can be replicated as "best practices" for other companies in Russia.

Thus, Sberbank is a self-learning organization that implements the following priority tasks: 1) creating an organizational climate in which employees are encouraged to learn and develop to reach their full potential; 2) promoting the culture of learning; 3) recognizing human resource development as the cornerstone of business policy; 4) maintaining continuous organizational transformation.

At the end of 2020, the largest Russian bank continued to be ranked eighth in Forbes list of Russia's top employers, leaving behind such companies as Yandex, Tinkoff Bank, and VTB. Organizational attractiveness helps to hire the best possible employees. Despite Sberbank's efforts to bring HR practices in line with the requirements of the digital economy, at the beginning of 2021 some banks and IT companies that are ranked higher than Sberbank in Forbes list of Russia's top employerslook better and, therefore, are more attractive for qualified professionals. 
Table 2. Sberbank's HR practices

\begin{tabular}{|c|c|c|c|}
\hline No. & HR management concepts & Management tools & Sberbank's HR practices \\
\hline 1. & \multicolumn{3}{|l|}{ Individual level } \\
\hline 1.1. & $\begin{array}{l}\text { Knowledge and innovation } \\
\text { workforce management }\end{array}$ & \multirow{2}{*}{$\begin{array}{l}\text { Core Competencies, } \\
\text { Employee Engagement } \\
\text { Systems, Balanced } \\
\text { Scorecard, TQM }\end{array}$} & $\begin{array}{l}\text { Corporate competency } \\
\text { model; 'An Effective Leader } \\
\text { - Inspiring and } \\
\text { Developing'; regular } \\
\text { assessment of engagement } \\
\text { scores and their dynamics }\end{array}$ \\
\hline 1.2 . & Talent management & & $\begin{array}{l}\text { Performance appraisal and } \\
\text { development cycle - } \\
\text { Employee Journey program; } \\
\text { Sberleaders competition; } \\
\text { Leaders Forum; tools for } \\
\text { talent acquisition and } \\
\text { management, goal setting, } \\
\text { and assessment }\end{array}$ \\
\hline 2. & \multicolumn{3}{|l|}{ Group level } \\
\hline 2.1. & $\begin{array}{l}\text { Horizontal coordination } \\
\text { mechanisms }\end{array}$ & Agile Management & $\begin{array}{l}\text { Horizontal interactions and } \\
\text { team management, regular } \\
\text { monitoring of team spirit, } \\
\text { HR platform }\end{array}$ \\
\hline 3. & \multicolumn{3}{|l|}{ Organizational level } \\
\hline 3.1. & $\begin{array}{l}\text { Strategic human resource } \\
\text { management }\end{array}$ & \multirow{3}{*}{$\begin{array}{l}\text { Strategic Planning, } \\
\text { Change Management } \\
\text { Programs, Digital } \\
\text { Transformation, Mission } \\
\text { and Vision Statements }\end{array}$} & $\begin{array}{l}\text { One of the bank's strategic } \\
\text { goals is to become an } \\
\text { employer of choice for } \\
\text { programmers; 'Personnel is } \\
\text { the bank's most important } \\
\text { asset and the basis of its } \\
\text { competitiveness' }\end{array}$ \\
\hline 3.2. & Organizational culture & & $\begin{array}{l}\text { Sberbank Group Culture 2.0: } \\
\text { Common DNA, engineering } \\
\text { culture }\end{array}$ \\
\hline 3.3. & Self-learning organization & & $\begin{array}{l}\text { Sberbank Corporate } \\
\text { University, Leaders Teach } \\
\text { Leaders [22] + The Leader } \\
\text { Who Had No Title [3], } \\
\text { organizational diagnostics }\end{array}$ \\
\hline
\end{tabular}

\section{Discussion}

It is not the first time that Sberbank, which implements one of the four principles of the digital economy (the principle of openness, according to Tapscott), is included in Forbes list of Russia's top 50 employers most attractive for highly qualified professionals. However, as of the end of 2020, the bank's management has not yet been able to achieve the previously set goal of making it into the top 5 best employers in Russia. Customer service depends on both the implementation of software solutions and the quality and intensity of communication between highly qualified employees: "to succeeds in the new economic environment, an organization must fight for the best employees, find and implement daring tools for their recruitment, development, and retention". 
Despite the positive dynamics and business achievements of such transparent companies as Sberbank, difficulties may arise in the implementation of the development strategy at the local level (as shown in the study by Sorokina and Shiryayeva), if the integrated promotion of the declared values and the development of a favorable organizational environment is not monitored continuously. Therefore, it is necessary to ensure that:

1)within the development of an efficient corporate culture in the bank, all employees accept corporate values that are strategically important for the bank's development, such as "teamness", which, in turn, involves the promotion of HR practices related to cooperation, sharing experience, continuous feedback using IT solutions,

2)there is a favorable social and psychological climate that contributes to staff involvement at all levels of management and allows to control staff turnover.

\section{Conclusions}

The corporate success of Sberbank, as the largest financial and tech company, is explained by its ability to adapt to the global trends of development of the information society. Therefore, the HR practices used by the bank can be replicated as business models and best management practices.

The objective of Sberbank's sustainable development is to "promote the digitalization of the economy". Technological progress, as one of the most important driving forces of globalization, ensures the introduction of information and communication technologies and updating of HR practices. If it were not for the cutting-edge HR innovations in line with the current trends, the management of Sberbank of Russia would not be able to implement the development strategy.

To avoid local difficulties in implementing the development strategy at the local level, leading to a decrease in the organization's overall attractiveness, Sberbank should objectively and regularly assess its progress in HR management advancement, focusing on the promotion of an innovation-oriented internal environment. The principles of organizational democracy and agile leadership should become the basis for the development of an advanced HR complex that meets the requirements of the digital economy.

\section{References}

1. A.A. Mad'jarov The use of management tools: some trends 2008-2017, Slavic forum , 31, 41-45, (2021)

2. M. Armstrong, The practice of human resource management. SPb.: Piter, (2017). -848 p.

3. D. N., Sokolov E. K. Zav'jalova, Integration of strategic resources of the organization in the conditions of the new economy: a conceptual model, Vestnik SPbGU. Menedzhment, T. 17, 46-68, (2018)

4.L. A. Sorokina, T. Shirjaeva, Strategic HR priorities of «Sberbank», Vestnik RUK, 39, 83$86,(2020)$

5.V. Ya. Tsvetkov, Information Models and Information Resources, European Journal of Technology and Design, 2 (12), 79-86, (2016)

6.S.V. Shaitura, K.V., Ordov, O.V. Pigoreva, I.V. Kosterina, D.A., Zyukin, V.G. Gerasimova, Problems of distance education, Revista Inclusiones. T. 7. № S4-1, 24-38, (2020) 
7.S.V., Shaitura, F.M., Feoktistova, A.M. Minitaeva, L.A. Olenev, V.O. Chulkov, Y.P. Kozhaev, Spatial geomarketing powered by big data Revista Turismo Estudos \& Práticas. № S5., 13. (2020)

8.D. Tapskott, Wikinomics: how mass collaboration changes everything, Intellektual'naja literatura, 456, (2020)

9.S.V. Shaitura, A.M. Minitaeva, K.V. Ordov, V.V. Shaparenko, Virtual enterprises in a spatial economy, International Journal of Recent Technology and Engineering (IJRTE) T. 7. № 6. ,719 - 724, (2019)

10.S.V. Shaitura, A.S. Nedkova, L.M. Tyger, E.D. Goryacheva, N.O. Morozova, L.V. Berketova, Food security and catering Revista Turismo Estudos \& Práticas № S3., 11, (2020)

11.S. Hayward, The Agile-leader: how to create an agile business in the digital age. Kogan Page, 224 (2018)

12.J.B.Quinn, P.Anderson, S. Finkelstein, Managing professional intellect: Making the most of the best, Harvard Business Review, 74, 71-80, (1996).

13.S.V., Shaitura, K.V., Ordov, A.M. Minitaeva, Digital learning methods for the digital economy, 1st International Scientific and Practical Conference on Digital Economy (ISCDE 2019). Proceedings of the International Scientific and Practical Conference. 606-611., (2019)

14.S.V. Shaytura, A.M. Minitaeva, V.M. Feoktistova, K.V. Ordov, Blockchains in spatial data security, CEUR Workshop Proceedings. Selected Papers of the X Anniversary International Scientific and Technical Conference on Secure Information Technologies (BIT 2019), 70-74, (2019)

15.A.P. Kupryushin, Innovative potential of digital economy in the process of import substitution and environmental management, Journal of Environmental Management and Tourism., T. 10. № 7 (39), 1617-1627 (2019)

16.V. Ya. Tsvetkov Information field Life Science Journal, T.11. №5, 551-554 (2014)

17.V.Ya. Tsvetkov, Informational intelligent management Modeling of Artificial Intelligence. № 4 (1), 46-54, (2017)

18.N. M. Tichy, The leadership engine: how winning companies build leaders at every level, HarperCollins, 452, (2007)

19.N.N. Shamsuddinov, Improvement of the state regulation of innovative development of the regional economy Theoretical \& Applied Science, 2 (82), 437-444. (2020)

20.V.V. Velikorossov, L.A.Chaikovskaya, S.A. Filin, Transfer pricing for taxation of transnational corporations under innovative economy conditions, 2nd International Conference on Contemporary Education and Economic Development (CEED 2019). "Education, Science, Technology, Innovation and Life", 97-103. (2019) 